\title{
Depressie en religie
}

\author{
P.A. Botha \\ Departement Sielkunde \\ Universiteit van Pretoria \\ PRETORIA
}

\begin{abstract}
Two contrasting roles regarding the mental health of man have been attributed to religion in the course of history. On the one hand, the presence of religion and faith in a person has been regarded as pathogenic, with the absence thereof as remedial. On the other hand religion and faith in a person have been regarded as remedial, with the absence thereof as pathogenic. The most important finding is that depression is an experience of paradoxes. If the person cannot offer any solution for the paradox, he remains trapped in the vicious spiral of depression. Expressed differently, despair is then constituted. The religious individual attempts to offer $a$ solution for the paradox through his interpretation of faith on the basis of his concept of God. Through a newly-discovered concept of God an interpretation of faith becomes possible by which the person discovers sense and meaning. Expressed differently, hope is then constituted.
\end{abstract}

\section{Inleidend}

In die loop van die geskiedenis is daar twee duidelike kontrasterende rolle aan religie toegeskryf. Aan die een kant word beweer dat religie die geestesgesondheid van die mens bevorder en aan die ander kant word weer beweer dat religie 'n potensiële bedreiging is vir die geestesgesondheid van die religieuse persoon. Van den Berg (1958:50) verwys na Pfister in hierdie verband.

De Christelijke religie, op ongeveer gelijke wijse als een analitische therapie, 's mensen angst vermag weg te nemen. In een breed opgezet historisch overzicht toont hij, dat het christendom zich van deze taak niet heeft gekweten. Meermalen is het christendom zelfs opgetreden als angstverwekker, door 's mensen vitaliteit te verdringen en angstvoorstellingen op te roepen. Daaruit ontstaden naast neurosen veel pathologiese vormen van religiositeit.

Aan die een kant word die teenwoordigheid van religie by 'n persoon gesien as patogeneties, met die afwesigheid daarvan as remediërend. Aan die ander kant weer, word religie en geloof by 'n persoon gesien as remediërend, met die 
Depressie en religie

afwesigheid daarvan as patogeneties. Hierdie onderskeie dimensies van die rol van religie kan voorgestel word soos in tabel 1.

Tabel 1: Die rol van religie by die religieuse persoon

\begin{tabular}{|l|l|l|}
\hline \multirow{2}{*}{ Religie } & \multicolumn{2}{|c|}{ Rol van religie } \\
\hline \multirow{2}{*}{ Aanwesig } & Remediërend & $\begin{array}{l}\text { Jung (1965) } \\
\text { Tillich (1952) } \\
\text { Van den Berg (1974) }\end{array}$ \\
\cline { 2 - 3 } & Patogeneties & $\begin{array}{l}\text { Freud (1971a) } \\
\text { James (1902) }\end{array}$ \\
\hline \multirow{2}{*}{ Afwesig } & Remediërend & Freud (1971a) \\
\cline { 2 - 3 } & Patogeneties & May (1939) \\
\hline
\end{tabular}

Sonder om in detail daarop in te gaan is dit tog nodig om te wys op die voorkeur vir die begrip religie. Religie is ' $n$ beter beskrywende en meer omvattende begrip as godsdiens. Die etimologiese oorsprong van religie dui onder andere op sowel die individuele as die intersubjektiewe dimensies van hierdie begrip. Die begrip religie sluit dan ook die daad en inhoud van geloof in, sodat die terme afwisselend gebruik kan word (Botha, 1991a).

Uit die bespreking en die literatuuroorsig wat volg, het depressie na vore getree as ' $n$ voorbeeld van 'n emosionele versteuring waarmee die tweeledige rol van religie by uitstek geillustreer kan word. Die ondersoek na die belewenis van depressie deur 'n religieuse persoon vloei hieruit voort. Die doelstelling van hierdie ondersoek is gerig op die bereiking van 'n goeie of akkurate beskrywing van die ervaring van depressie deur 'n religieuse persoon. Hierdie ondersoek wil op grond van 'n goeie beskrywing 'n bydrae lewer ten opsigte van moontlike psigoterapeutiese en psigo-pastorale implikasies. Vosloo en Bisschoff (1989) het juis in hulle ondersoek bevind dat predikante aangedui het dat pastorale sorg 'n prioriteit in gemeentewerk is. Hierdie predikante het egter beleef dat hulle vaardighede en kennis in pastorale versorging ontoereikend is. Die implikasies van hierdie ondersoek sou van toepassing kon wees op die pastor as prediker en berader, op die psigoterapeut sowel as op die geloofsgenote (Polkinghorn, 1989; Wilson, 1984). Die navorsingsmetode wat by uitstek geskik is om ' $n$ goeie beskrywing te verkry, is die fenomenologiese metode, maar later meer oor die metode.

\subsection{Pastorale versorging van die depressiewe persoon}

Jordan (1986) gee enkele riglyne vir die hantering van die depressiewe gelowige: 
* Skrifgedeeltes kan aangehaal word om die peroon se foutiewe siening van die werklikheid te verander.

* Werk met 'n sisteembenadering waarin eksterne faktore in ag geneem word en gee aandag aan die persoon se sosiale ondersteuningsstelsel.

* Soek begrip vir die ervaring van depressie.

* Intervensies vanuit ' $n$ teologiese perspektief moet nie verdere skuldgevoelens ontlok nie.

* Help persone om sin en betekenis te ontdek en vestig so hoop.

Du Toit (1984) lê klem op die volgehoue kontak met die depressiewe persoon, die hantering van probleemvrae vanuit 'n Bybelse perspektief, die nasorg wat gerig is op geloofsekerheid en herstel van die geloofslewe, en die omsien na die naasbestaandes. Alhoewel bogenoemde riglyne praktiese waarde het vir die predikant as pastor, is daar tog leemtes in terme van 'n sielkundige perspektief op hierdie saak. Hierdie ondersoek wil vanuit 'n sielkundige perspektief 'n bydrae lewer ten opsigte van die psigo-pastorale versorging van die depressiewe persoon. Om depressie by die gelowige in perspektief te verstaan moet daar eers in meer besonderhede besin word oor die remediërende en patogenetiese rol van religie.

\section{Die remediërende en patogenetiese rol van religie}

\subsection{Die remediërende rol van religie}

Die woord remediërend kan etimologies terugevoer word na die Latynse woord remedium wat geneesmiddel beteken (Postma, 1982). Die voorvoegsel re beteken dan ook, (a) in opposisie, (b) terug na 'n vorige staat voor die insinking of (c) nuut daarstel. Religie as remedie sou dan hiervolgens beteken dat die psigiese homeostase van die persoon in stand gehou word, herstel word en/of nuut daargestel word. Hierdie verklaring sluit ook aan by Sykes (1984:878) se verklaring van remedie as ' $\mathrm{n}$ "cure for or against disease, healing medicine or treatment; means of counteracting or relieving anything undesirable".

Verskeie skrywers wys op die remediërende rol van religie deur verskillende aspekte te beklemtoon. Volgens Flannery en Bowen (1984) voorsien religie ' $n$ transendentale betekenis aan die lewe van die gelowige as 'n wyse waarop betekenis in die wêreld ontdek kan word. Volgens Yalom (1980) word die mens gekonfronteer met betekenisloosheid vanweë onder andere die gebrek aan 'n religieus-gebaseerde kosmiese betekenissisteem. Die betekenisloosheid van die moderne lewe soos dikwels gevind word "in the neuroses so eloquently described by Victor Frankl is due to a failure in our quest to discover those sets of meanings which motivate us to a fuller, richer life" (Kruger, 1988:37). Religie as 'n sisteem 
Depressie en religie

waardeur betekenis ontdek kan word, is duidelik 'n belangrike funksie van religie By die depressiewe persoon met sy kenmerkende pessimistiese ingesteldheid en sy gevoelens van die sinloosheid van die lewe, sou religie as 'n sin-ontdekkende betekenissisteem by uitstek relevant wees. Hierdie religieuse denkraamwerk of paradigma berus op die leerstellinge wat gewoonlik gegrond is op die een of ander 'Heilige Boek' van die bepaalde religieuse gemeenskap. Volgens Jordaan en Jordaan (1989) is die paradigma die denkraamwerk van waaruit vrae gevra word en antwoorde verkry word. Die religieuse denkraamwerk is dus 'n belangrike bron van waaruit die gelowige vrae kan vra en antwoorde kan kry. Hierdie denkraamwerk of leerstellinge kom ooreen met die aspek van geloof waarna Kuitert (Botha, 1981) verwys as fides quae creditur. Hierdie aspek verwys na die aanvaarding van sekere geloofswaarhede as waar. Hierteenoor onderskei hy 'n ander aspek van geloof, naamlik die daad van vertroue en geloof in God wat hy fides qua creditur noem. Die twee aspekte van geloof is in 'n dinamiese interaksie met mekaar en beïnvloed mekaar wedersyds. Albei aspekte van geloof konstitueer die ervaring binne die verhouding met God. Op sy beurt beïnvloed die ervaring van God weer sowel fides qua as fides quae (Botha, 1981; 1991a) Wanneer die patogenetiese rol van religie aan die orde kom, sal die fides quae, soos byvoorbeeld die konsep van God, uitgelig word as 'n belangrike bron van religieuse depressie (Cumbee, 1980).

Tillich (1952) en Benjamin (1972) wys op die noue relasie tussen geloof en die integrasie van die persoonlikheid. Benjamin (1972:49) beskryf religieuse geloof as 'n "integrating force in the personality". Flannery en Bowen (1984) het bevind dat die voorkoms van angs en depressie laer was by religieuse persone as by niereligieuse persone. Hulle wys verder daarop dat religie die individu sosiaal integreer met die gemeenskap. Hierdie sosiale dimensie van religie vervul die belangrike rol van die kleingroep wat volgens Van den Berg (1974) kenmerkend is van die gesonde samelewing. In die bogenoemde eksemplariese verwysing na die remediërende rol van religie wil dit voorkom asof religie 'n denkraamwerk daarstel wat integrasie bevorder op die intra-psigiese en interpersoonlike vlakke. Hierdie siening verteenwoordig 'n geïntegreerde konseptualisering van die mens waarin ' $n$ positiewe verhouding aangedui word tussen gesonde religiositeit en algemene geestesgesondheid. 'n Positiewe verband tussen gesonde religieuse toewyding en geestesgesondheid is ook meestal bevestig deur navorsing (Ellison \& Smith, 1991; Gartner et al., 1991). So maak Poloma en Pendleton (1991:81) die gevolgtrekking dat hulle ondersoek "clearly delineates patterns by which various measures of religiosity, most notably 'relationship with God,' 'prayer experiences,' and 'church attendance,' provide for greater general life satisfaction, greater existential well-being, happiness, and religious satisfaction". 


\subsection{Die patogenetiese rol van religie}

Verskeie skrywers waaronder Cumbee (1980) en Hark (1984) verwys na ekklesiologiese neuroses. Die woord ekklesia kom van die Griekse woord wat verwys na 'n vergadering van algemene, politieke of religieuse aard (Arndt \& Gingrich, 1979). Ekklesia verwys dus na neuroses waarin die kerk 'n beduidende rol gespeel het in die ontwikkeling daarvan. Een van die tipe religieuse neuroses waarna Cumbee (1980) verwys, is depressie. James (1902) het met die eeuwending al na hierdie tipe depressie verwys as religieuse melancholie. Religieuse depressie verwys dan na ' $n$ spesifieke emosionele versteuring waarin religie ' $n$ beduidende rol speel in die patogenese daarvan. Volgens Gruber (1978) is die eerste verwysing na religieuse depressie opgeteken in die verhaal van Kain en Abel in Genesis 4. In die Nuwe Afrikaanse Bybel (1983:14) word vers 5 vertaal met: "Kaïn het baie kwaad geword en hy was bedruk." Volgens Gruber (1978) dui die Hebreeuse uitdrukking 'die neus brand', nie op die tradisionele verklaring van kwaad wees nie, maar op depressie soos geimpliseer word in vers 5 . Die verband tussen depressie en aggressie wat hierdie uitdrukking geimpliseer word, word in die psigodinamiese teorie ondersteun. In hierdie teorie word melding gemaak van selfgerigte aggressie in depressie (Cameron \& Rychlak, 1985). In die verhaal van Kaiin en Abel word Kaïn verwerp deur God, waardeur hy (Kaïn) 'n liefdesobjek verloor het - met die gevolglike verlies aan selfagting en die rig van woede op homself. Hierdie verklaring sluit nou aan by die psigoanalitiese teorie en by die bronne van religieuse depressie volgens Cumbee (1980). Hy noem die onderstaande vyf bronne:

* 'n Morbiede, valse of neurotiese skuldgevoel. Die sogenaamde onvergeefbare sondes is ' $n$ voorbeeld hiervan. Opmerkings wat hieronder tel is: " $n$ Christen mag nooit depressief wees nie' of 'As jy aan depressie ly is jy nie waarlik gered nie'. Hierdie opmerkings berus dan volgens die verkondigers daarvan op Bybelse gronde (fides quae).

* Wanhoop wat die gevolg is van die onvermoë van 'n persoon om volledig die wil van God (fides quae) te kan uitvoer.

* Die 'wurm'-teologie beklemtoon die sondigheid van die mens. Hierdie besef kan teweeggebring word deur die amptelike verkondiging (fides quae) en/of kerklike praktyke.

* Die Uria-sindroom verwys na die gelowige wat deur sy geloofsgenote in die steek gelaat en daarom kwesbaar is

* Religieuse seksisme dui op die sogenaamde minderwaardigheid van die vrou teenoor die man op Bybelse gronde (fides quae)

* Die konsep van God is 'n belangrike bron van religieuse depressie wat Keady (1980) byvoeg. Dit wys op die rol wat die konsep van God (fides 
quae) speel in die patogenese van religieuse depressie by die gelowige persoon. In aansluiting by bostaande bespreking oor die wedersydse beinvloeding van geloof en ervaring, wys Heinrichs (1982) tereg daarop dat die konsep van God 'n verhoudingsbeeld en 'n ervaringsbeeld van God reflekteer. Omdat die konsep van God 'n verhoudingsbeeld is, is dit ook onderwerp aan parataktiese distorsies. 'n Parataktiese distorsie kan beskryf word as enige houding teenoor ' $n$ ander persoon wat berus op ' $n$ gefantaseerde of versteurde evaluasie van daardie persoon, of 'n identifisering van so 'n persoon met ander figure uit die persoon se lewe (Sullivan, 1953). Hierdie beskrywing van parataktiese distorsies sluit nou aan by Freud (1971b) se siening van oordrag, met die verskil dat oordrag manifesteer in die psigoterapeutiese verhouding. Die distorsies of oordrag soos wat dit na vore kom in relasie met die konsep van God, het belangrike psigoterapeutiese implikasies vir religieuse depressie, maar hieroor later meer. In die ondersoek wat onderneem is, het dit ook geblyk dat die konsep van God 'n sleutelrol speel in sowel die patogenese as die remediëring by depressie.

Om die dinamika van depressie met betrekking tot religie beter te verstaan is dit nodig om kennis te neem van enkele van die teoretiese benaderings.

\section{Patogenese van depressie}

Met die keuse vir die fenomenologiese navorsingsontwerp vind die ondersoek ook die meeste aansluiting by die werk van Tellenbach (1980) oor melancholie. Sy siening vanuit 'n fenomenologiese benadering het belangrike implikasies vir die verstaan van depressie by die religieuse persoon. Die begrippe en konsepte wat hy gebruik, sluit goed aan by die taal van die religieuse persoon. Drie ander hoofbenaderings, naamlik die psigodinamiese, kognitiewe en eksistensicel-fenomenologiese benadering sal gesamentlik in oënskou geneem word in 'n poging om 'n meerdimensionele integrasie voor te stel.

\subsection{H. Tellenbach: die fenomenologiese benadering}

\subsubsection{Endogeniteit as oorsprong}

Tellenbach (1980) onderskei drie kousale velde, naanlik die soma of liggaam, die psige en die endon. Endogeniteit verwys na die ritmiese en vitale aspekte van die totale mens wat verband hou met die oorerflikheidsfaktore wat in die ontwikkeling van die mens (biologies en psigies) na vore kom. Die endogene verandering kan dus aan die een kant dui op die positiewe aspek van die aktualisering van die moontlikhede van die mens. Aan die ander kant verteenwoordig melancholie 'n mislukking van endon. Volgens Tellenbach (1980) dui melancholie op 'n geneties beslissende trek of anders gestel, 'n spesifieke fenotipe. Hierdie genetiese 
predisposisie staan in 'n dinamiese relasie met die omgewingskragte on die fenotipe te laat realiseer, naamlik die tipus melancholikus of die tipiese melancloliese persoonlikheidstruktuur.

\subsubsection{Tipus melancholikus}

Volgens Tellenbach (1980) is daar 'n opvallende konsekwente en bestendige voorkoms van essensiële kenmerke teenwoordig by die tipus melancholikus:

\subsubsection{Die fiksasie op ordelikheid}

Die kritiese onderskeidende kenmerk van die tipus melancholikus is nie net die ooraksentuering van orde nie, maar sy gefikseerdheid op orde. Hierdie gefikseerdheid op orde kan voorkom ten opsigte van alle lewensareas of net in een essensiële lewensarea. Die melancholiese persoon laat niks aan die toeval oor nie want, toeval is wan-orde. Die persoon gee voorkeur aan 'n vasgestelde program en geen inmenging met die program word geduld nie. Die persoon is vasgevang binne sy eie onbuigsame grense en hy "always stands within his orders and at the same time over and beyond them" (Tellenbach, 1980:122). Die melancholiese persoon is vasgevang binne hierdie paradoksale selfkontradiksie waarvoor hy geen oplossing het nie. Alhoewel hy aanvanklik die standaarde vir orde daarstel en dit beheer, bevind hy hom later in die dilemma dat hy nie meer in beheer is van sy standaarde nie, maar dat dit hom beheer. Hy word kompulsief daardeur gedryf en hyself is nie meer die dryfveer daarvan nie.

\subsubsection{Die patogenese van melancholie}

Die tipus melancholikus staan ook weer in 'n dinamiese interaksie met die omgewing waarin liy homself bevind. Hierdie besondere situasie konstitueer die premelancholiese situasie waarin die konstellasies van remanens en inkludens voorkom. Hierdie situasie gee weer aanleiding tot 'n belewenis van selfkontradiksie of V'erzweiflung wat die inisiële melancholiese fase kenmerk. Die finale fase is dan die 'moment' van verandering wat die melancholiese situasie inlei. Ter wille van beter begrip is dit egter nodig dat die onderskeie aspekte van die patogenese kortliks aan die orde kom (vgl. Tellenbach, 1980).

\subsubsection{Die pre-melancholiese situasie}

Dié situasie is vir Tellenbach (1980:132) altyd "a cross-section through the existing context of I and the world. I am always standing within a situation and I am incapable of leaving it without entering into another". Wanneer ek gekonfronteer word met 'n situasie of die situasie transendeer, het die situasie alreeds verander in 'n nuwe een, waarin die Ek-werêld-relasie, en die Ek-self-relasie nuut 
Depressie en religie

getransformeer is. Die nuwe situasie of die verandering van die (uiterlike) eise van die situasie vereis die noodsaaklikheid van 'n (innerlike) strukturele aanpassing. By die melancholiese persoon is dit juis hierdie onvermoë om aan te pas wat die spesifieke situasie daarstel. Wanneer die spesifieke persoonlikheidstruktuur van die tipus melancholikus in relasie staan met die spesifieke situasie soos 'n sleutel in 'n slot - ontstaan die pre-melancholiese situasie (Kraus, 1979; Tellenbach, 1978). Die pre-melancholiese situasie is dus 'n manifestasie van die tipus melancholikus se fiksasie op orde. Dit moet beklemtoon word dat dit die tipiese in die persoon is wat die situasie verander in 'n patogenetiese situasie. Hierdie genetiese predisposisie van die tipus melancholikus staan in 'n dinamiese interaksie met sy omgewing. In die omgaan met sy omgewing konstitueer hy sy situasie al meer in die rigting van die konstellasies van inkludens eil remanens (Blankenburg, 1989; Tellenbach, 1980; 1983).

\subsubsection{Die konstellasie van inkludens}

Inkludens verwys na die selfinsluiting van die persoon binne grense. Die kritiese moment wat die verandering in die situasie teweegbring om al meer na inkludens te beweeg, is die self-kontradiksie. Die selfkontradiksie vind plaas wanneer die persoon so ge-enkapsuleer word binne sy eie gestelde grense dat hyself nie meer daaruit kan kom nie. Die persoon se fiksasie op ordelikheid is so inperkend dat dit homself opponeer en tog kan hy sy eie orde nie ontsnap of trarisendeer nie. Hierdie fenomeen van inkludens is 'n beslissende patogenetiese aspek in die ontwikkeling van melancholie.

\subsubsection{Die konstellasie van remanens}

Die kritiese moment van remanence kom oral na vore as in-die-skuld-wees. Hierdie in-die-skuld-wees dui op die diskrepansie tussen 'n persoon se eise wat hy aan homself stel en sy prestasie en die oortreding van etiese of religieuse voorskrifte. Hierdie in-die-skuld-wees kom na vore in 'n kwalitatiewe 'nie goed genoeg' te wees nie of 'n kwantitatiewe 'nie genoeg nie'. Die in-die-skuld-wees (default: debet) word dan die persoon se misstap (fault: culpa) en kom na vore in die vorm van skuld. Die situasie van remanens word beleef as selfkontradiksie wanneer die persoon poog om 'n situasie van in-die-skuld-wees te ontsnap en tegelyk vasgevang te wees binne die selfgestelde eise. Om die een situasie van indie-skuld-wees te ontsnap, beteken dat die persoon onmiddelik in ' $n$ ander situasie van in-die-skuld-wees vasgevang word. Wanneer die persoon gereeld sy skuld bely, kry hy insig in die omvang van sy skuld. So kan 'n religieuse bekering of skuldbelydenis die sneller wees vir die aanvang van 'n melancholiese episode. So 'n persoon word dan 'n gevangene van sy eie geskiedenis van skuld. Tellenbach $(1980: 160)$ verduidelik dit dat "in the remanence of the current indebtness all former being in debt can become contemporary because of the original co- 
herence of guilt in existence". Hierdie konstellasie bring 'n toenemende belemmering van selfaktualisering mee, tot op die punt van 'n eksistensiële stilstand.

\subsubsection{Vertwyfeling en die inisiële melancholiese fase}

In elke pre-melancholiese fase kom sowel konstellasies van remanens as inkludens voor. Verzweiflung is die brug tussen die end van die pre-melancholiese fase en die aanvang van die melancholiese episode. Hierdie vertwyfeling dui daarop dat die persoon vasgevang is in twyfel, vasgevang tussen moontlikhede waarvan nie een gerealiseer word nie. Hierdie vertwyfeling is nie ' $n$ eindpunt van desperaatheid of moedeloosheid nie, maar 'n beweging tussen, vorentoe en agtertoe, 'n omwisseling sodat 'n definitiewe keuse nie langer moontlik is nie. Die persoon sien die selfkontradiksies van die pre-melancholiese fase raak, maar is nie in staat om dit op te los nie.

\subsubsection{Die moment van verandering: die melancholiese fase}

Die moment van verandering kom na vore in die verhouding van die self tot sy tema. Die self beheer nie meer sy tema (byvoorbeeld orde of eise) nie, maar word deur sy tema beheer. Die persoon is dus nie meer in staat om sy situasie van in-die-skuld-wees te transendeer nie. Alhoewel die situasie kan verander, bly die tema, skuld, onveranderd. Die tema transendeer die persoon sodat die persoon nie in staat is om hom met die tema te bemoei nie en dit dus ook nie kan bemeester nie.

\subsection{Integrasie: enkele van die hoofbenaderings}

Die benadering bepaal die artikulering en daarom artikuleer en belig die onderskeie benaderings 'n fenomeen soos depressie ook uniek. Wanneer fenomenologies gekyk word na die benaderings is dit opvallend dat daar deur almal 'n goue draad van essensiële ooreenkomste loop. So byvoorbeeld is dit die unieke van die persoon wat die situasie verander in 'n patogenetiese situasie. Daar is deurlopend sprake van 'n tipe persoon wat kwesbaar is vir depressie en wat in interaksie is met 'n besondere soort situasie. In tabel 2 en 3 word die psigoanalitiese (Freud, 1971c), kognitiewe (Beck, 1976) en die eksistensieel-fenomenologiese (Tellenbach, 1980) benaderings ter illustrasie aangebied. 
Tabel 2: Die persoon-situasie-interaksie

\begin{tabular}{|c|c|c|}
\hline \multirow{2}{*}{ Benadering } & \multicolumn{2}{|l|}{ Faktore in interaksie } \\
\hline & Persoon & Situasie \\
\hline $\begin{array}{l}\text { Psigoanalities } \\
\text { (Freud) }\end{array}$ & $\begin{array}{c}\text { Narsisties } \\
\text { Oraalgefikseerd } \\
\text { Obsessioneel-superego }\end{array}$ & Objekverlies \\
\hline $\begin{array}{l}\text { Kognitief } \\
\text { (Beck) }\end{array}$ & $\begin{array}{l}\text { Depressie-geneig } \\
\text { Sensitief vir verlies } \\
\text { Opvoeding- } \\
\text { perfeksionisties }\end{array}$ & $\begin{array}{l}\text { Persoonlike } \\
\text { domein se } \\
\text { verlies }\end{array}$ \\
\hline $\begin{array}{c}\text { Eksistensieel- } \\
\text { fenomenologies } \\
\text { (Tellenbach) }\end{array}$ & $\begin{array}{l}\text { Tipus melancholikus } \\
\text { Fiksasie op orde }\end{array}$ & Versteurde orde \\
\hline
\end{tabular}

In die dinamiese interaksie tussen die persoon en die situasie word 'n antitese of paradoks gekonstitueer tussen twee essensiële aspekte en 'n onsuksesvolle poging aangewend tot sintese of 'n onvermoë ontstaan om 'n suksesvolle oplossing aan te bied. Die onsuksesvolle poging verteenwoordig die kardinale punt waar daar beweeg word na die aanvangsfase van depressie (Botha, 1991a; 1992). Tabel 3 illustreer weer eens slegs drie benaderings.

Tabel 3: Die oorgangsfase na depressie

\begin{tabular}{|c|c|l|}
\hline Benadering & \multicolumn{2}{|c|}{ Oorgangsfase na depressie } \\
\cline { 2 - 3 } & Paradoks & $\begin{array}{l}\text { Onsuksesvolle } \\
\text { oplossing }\end{array}$ \\
\hline $\begin{array}{c}\text { Psigoanalities } \\
\text { (Freud) }\end{array}$ & $\begin{array}{c}\text { ID (haat) } \\
\text { versus } \\
\text { Superego (liefde) }\end{array}$ & $\begin{array}{l}\text { Ego rig } \\
\text { aggressie } \\
\text { op self }\end{array}$ \\
\hline $\begin{array}{c}\text { Kognitief } \\
\text { (Beck) }\end{array}$ & $\begin{array}{c}\text { Realistiese kognisies } \\
\text { versus }\end{array}$ & $\begin{array}{l}\text { Vasgevang in } \\
\text { bose kringloop }\end{array}$ \\
\hline $\begin{array}{c}\text { Eksistensiecl- } \\
\text { fenomenologies } \\
\text { (Tellenbach) }\end{array}$ & $\begin{array}{c}\text { Fiksasie op orde } \\
\text { versus }\end{array}$ & Verzweiflung \\
\hline
\end{tabular}


Die voorafgaande bespreking kan saamgevat word deur te sê dat die patogenese van depressie gaan oor 'n spesifieke tipe persoon wat in interaksie met 'n bepaalde tipe situasie 'n dilemma beleef waarvoor hy nie 'n oplossing het nie. Ons het dus in die verskillende benaderings ook verskillende, maar klaarblyklik ewe geldige beskrywings van depressie. Verskillende benaderings behoort dus eerder komplementêr gesien te word - 'n uitgangspunt wat in hierdie ondersoek wel die geval is. Met die bogenoemde uitgangspunt in gedagte, wil hierdie ondersoek die kenmerkende trekke in die depressiewe belewenis van die religieuse persoon van naderby beskou. Dit is egter nodig om die fenomenologies-eksistensiële navorsingsontwerp kortliks te bespreek.

\section{Die navorsingsmetode}

Die fenomenologiese navorsingsontwern is vir genoemde ondersoek gebruik. Die basiese beginsel wat onderliggend is aan hierdie metode, is dat die ondersoeker getrou bly aan die feite soos dit besig is om te gebeur. Daar is dus 'n respek vir die fenomeen en daarom is die ingesteldheid van die ondersoeker om die fenomeen toe te laat om vir homself te praat. Hierdie benaderingswyse sluit aan by Husserl (Kruger, 1988:28) se leuse van 'terug na die dinge self' (Zurück zu den Sachen). Die ondersoeker se primêre doel is om waar te neem en die fenomeen so akkuraat as moontlik te beskryf. Die ondersoeker poog dus om te kom tot 'n toereikende begrip vir die fenomeen soos wat dit self manifesteer, met die minste moontlike beïnvloeding van sy eie vooroordele en idees of pogings om dit te verklaar in terme van bestaande teoretiese raamwerke. By die metode wat hier gevolg is, was die produk ' $n$ integrasie van 'n verskeidenheid bydraes (Giorgi, 1985; Kruger, 1988; Kvale, 1983; Wertz, 1983). Die navorsingsmetode kan kortliks soos volg weergegee word:

\subsection{Loodsstudie}

'n Loodsstudie is onderneem waarna 'n gepaste fokusvraag ontwikkel is en soos volg geformuleer is:

'Vertel of beskryf hoe dit vir $u$ as Christen-gelowige is om depressief of terneergedruk te wees. Hoe en wat beleef $u$ van God en die gemeente wanneer u terneergedruk of depressief is? Hoe is dit om so terneergedruk te wees? Beskryf hierdie gevoelens of gedagtes net soos dit is. Moenie ophou vertel voordat $u$ so volledig moontlik vertel het hoe dit vir $u$ as gelowige is om so terneergedruk te wees.' 


\subsection{Selektering van die ondersoekgroep}

Die persone moes religieuse persone wees. Vir die doel van hierdie ondersoek moes die persone belydende Christene wees. Verder moes die persone ' $n$ belewenis van depressie gehad het en gediagnoseer gewees het in terme van die DSM-III-R-klassifikasiestelsel met 'n gemoedsversteuring. Die drie persone wie se beskrywings geanaliseer is, het 'n diagnose gehad van 'n major depressie. Om persone vir hierdie ondersoek te vind is 'n pastorale sielkundige genader. 'n Lys van name is deur hom beskikbaar gestel. Hierdie persone is telefonies genader en 'n afspraak is gemaak vir die navorsingsonderhoud. Ander kriteria het onder andere behels dat die persone gewillig moes wees, beskikbaar en die verbale vermoë moes hê om ervarings te kon deel. Uiteindelik is sewe beskrywings verkry waarvan drie geanaliseer is.

\subsection{Die navorsingsonderhoud}

Tydens die onderhoud is ' $n$ gepaste fokusvraag gevra en daar is van ophelderende vrae gebruik gemaak om onduidelikhede te verhelder. Die onderhoud is op oudioband opgeneem en later verbatim getranskribeer.

\subsection{Die data-analise}

Die metode wat gevolg is, kan kortliks in ses stappe saamgevat word.

Stap 1: Die intuittiewe holistiese begrip van die vertellings:

Die navorser lees met 'n onbevooroordeelde houding die beskrywing soveel keer deur as wat nodig is om ' $\mathrm{n}$ geheelindruk te kry, maar geen ontleding word nog gemaak nie.

Stap 2: Die afbakening van natuurlike betekeniseenhede:

Die navorser lees die beskrywings nog stadiger deur en merk die teks elke keer waar daar 'n oorgang in betekenis waargeneem word. Elke betekeniseenheid word voorsien van 'n kemagtige beskrywing of sentrale tema.

Stap 3: Eliminering van oorbodighede in die vertellings:

Drie beskrywings is gekies om verder ondersoek te word nadat seker gemaak is dat geen essensiële betekeniseenhede verlore sou gaan nie. Verder word alle irrelevante opmerkings wat nie betrekking het op die fenomeen nie in die beskrywing weggelaat.

Stap 4: Die deeglike refleksie en eksplisering van die vertellings:

Die navorser gaan voort om te besin oor die natuurlike betekeniseenhede en die sentrale temas wat nog steeds in alledaagse taal van die beskrywing is en transformeer dit in formele sielkundige taal. 
Stap 5: Die gesitueerde beskrywing verwys na die unieke beskrywing ten opsigte van die individu in 'n spesifieke konteks.

Stap 6: Die algemene beskrywing verwys na die universele beskrywing ten opsigte van die essensiële invariante betekenisstruktuur van die fenomeen oor die verskeie individue heen. Hierdie beskrywing kommunikeer die betekenisstruktuur in die algemeen en poog om die beperkinge van die spesifieke konteks te oorbrug.

\section{Resultate}

Die resultate wat hier volg, is 'n samevattende integrasie van die algemene struktuur van die belewenis van depressie deur religieuse persone. Alhoewel die navorsingsdoelstelling gerig was op die religieuse en geloofsaspekte, is dit egter duidelik dat hierdie aspekte nie in isolasie beleef of hier beskryf kan word nie. Die klem sal in hierdie beskrywing geplaas word op die religieuse aspekte. Wanneer verwys word na die persoon, is die bedoeling dat dit verwys na 'n religieuse of gelowige persoon. Ter wille van die gemaklike verwysing na die oorspronklike beskrywings, sal daar van skuilname gebruik gebruik gemaak word on die persone se identiteit te beskenn. Die drie persone waanna verwys sal word, is (a) Alta (36 jaar oud en geskei sonder kinders), (b) Ben (45 jaar oud en getroud met kinders) en (c) Clara (43 jaar oud en 'n weduwee met kinders).

\subsection{Die aanvang van depressie}

\subsubsection{Die pre-depressiewe situasie}

Die pre-depressiewe situasie is een waarin die status quo verander en die ordelike lewenswyse van die persoon versteur is. Die verandering word dikwels genoodsaak deurdat die persoon poog om die een situasie van in-die-skuld-wees te ontsnap maar dat hy homself onmiddellik weer in 'n ander situasie van in-dieskuld-wees bevind. Die veranderde situasie bring veranderde eise mee waarby die persoon moet aanpas. Die aanpassing by die nuwe situasie is so veeleisend dat die persoon 'n onvermoë beleef om eise suksesvol te hanteer vanweë die oorskryding van sy elastisiteitsperk

"Ek sien dit as moeilike omstandighede wat oor my gekom het ... en ... en ek het net psigies nie kon ... ek het oorspanne geraak" (Clara)

Die paradoks van verandering word gekonstitueer deurdat die persoon vasgevang is tussen twee situasies waaruit hy nie kan ontsnap nie. Albei situasies is vir hom onaanvaarbaar of onmoontlik. Terug kan hy of wil hy nie, want die nuwe situasie is juis ' $n$ noodgedwonge verandering in ' $n$ poging om die ou situasie te ontsnap. 


\subsubsection{Die psigiatriese intervensie}

Die depressiewe persoon beleef die aanvanklike psigiatriese besoek as traumaties en vernederend.

"Daai dag toe ek ... die psigiater gaan sien het, was vir my verskriklik gewees dat ek sover moet gaan dat ek 'n psigiater moet gaan sien. Ek kon dit omtrent nie verwerk nie ... ek het vir dae lank met daai storie ... probleem geworstel ... dit was nie vir my 'n probleem gewees om die kliniese sielkundige te gaan sien nie, maar toe ek op die punt kom dat ek 'n psigiater moes gaan sien het, was dit nou vir my rêrig 'n klad op my naam gewees ... 'n klad op 'n ou se selfbeeld ... ek dink 'n ou se selfbeeld vat 'n verskriklike knock in so 'n situasie ..." (Ben).

Om gediagnoseer te word beleef die persoon as om gebrandmerk te word as 'n geestesversteurde wat nie opgewasse is om lewenseise te kan hanteer nie.

"Toe dit eers gediagnoseer is en ek eers in 'n kliniek was ... toe verloor ek daardie bietjie selfvertroue wat ek gehad het om myself deur te trek ... nou ek weet ... ek weet dit is belaglik, ek weet ' $n$ mens moet nie gestigmatiseerd voel nie ... maar ... . dit ... dit is vreeslik swaar as iemand van hierdie situasie praat as ... as ' $n$ emosionele versteuring, want dan voel ' $n$ mens soos ' $n$ geestelike versteurde" (Clara)

Hierdie stadium is 'n kritiese punt waar die perșoon sy eie magteloosheid erken met die gepaardgaande verlaging van sy eiewaarde. Hierdie stadium is sowel die keerpunt as die beginpunt van 'n bose kringloop waarin die persoon 'n toenemende onsekerheid oor homself beleef in al hoe meer lewensituasies.

\subsection{Religie en fides}

\subsubsection{Depressie as 'n geloofstryd}

Die persoon beleef depressie as ' $n$ intense geloofsworstelstryd van diskrepansies en anomalieë wat lei tot ernstige geloofstwyfel.

"Ek beleef dit as ' $n$ vreeslike stryd ... omdat ek dink 'n gelowige behoort nie so te voel nie ... omdat ek dink joe! ... want as ek geloof gehad het sou ek nie hierdie vreeslike angste en goed belewe het ... regtig baie mense het al vir my gesê: 'as jy net die geloof het ... dan sal jy nie so voel nie' ..." (Alta).

Die geloofstryd is ' $n$ poging om orde terug te vind te midde van die diskrepansies en anomalieë. Die geloofstryd vind plaas op verskillende vlakke: 


\subsubsection{Sin en betekenis}

Die persoon worstel met die anomalieë belewenisse waarin vrae gevra word na die doel van God se optrede. Deur vas te hou aan enkele geloofswaarhede, maak die persoon geloofsinterpretasies en kan so nuwe sin en betekenis in sy depressie ontdek. Die nuwe ontdek van sin en betekenis konstitueer hoop.

"En dit is een van die punte waar ek vir my 'n ligpunt sien vorentoe, dat ek deur hierdie situasie moet gaan en God dra my hierdeur sodat ek moet weet presies hoe dit voel ... om in hierdie situasie te wees, want vorentoe gaan Hy my gebruik om mense te lei ... so in dié opsig het ek dan ook aan vasgeklou aan my geloof" (Ben).

\subsubsection{Fides quae en fides qua}

Die persoon beleef God as gedistansieerd en onbetrokke. Die belewenis van God konstitueer 'n diskrepansie tussen die persoon se konsep van God (fides quae) en sy belewenis van God. In die afwesigheid van die Goddelike ingrepe in die depressiewe lyding van die persoon word wanhoop gekonstitueer. Hierdie diskrepansie lei ook daartoe dat die persoon sy konsep van God bevraagteken. Die persoon kan byvoorbeeld die almag en liefde van God bevraagteken in die lig van sy belewenis van God. Wanneer God nie ingryp nie, word die vraag gevra of God werklik almagtig is en of Hy die God van liefde is. Die diskrepansie tussen die persoon se konsep van God en sy belewenis van Hom konstitueer die belewenis van 'n geloofsparadoks. Die persoon beleef dan 'n onvermoë om sy bestaande konsep van God te aanvaar as die waarheid (fides quae) en/of 'n onvermoë om op Hom te kan vertrou (fides qua). In albei gevalle word die onvermoë om te glo beleef as sonde en dus as 'n situasie van in-die-skuld-wees by God. Die gevolglike skuldgevoelens intensifiseer weer die depressie.

"Ek ervaar Hom soms as onbetrokke, dat Hy maar daar bo sit en net kyk wat aangaan ... nie regtig omgee nie ... en soms wonder ek intensief of Hy liefde is ... en as Hy liefde is ... is Hy dalk nie Almagtig nie ... want as Hy Almagtig is kan ... sal Hy dalk nie al die dinge toelaat ... wat hy Hy wel toelaat nie ... die Vader van alles ... die Gewer van alles en dan partykeer dan dink ek nee ... Hy vat ook alles ... en dan dink ek ... ag Here, hoekom vat $U$ nie ook maar die res wat nog oor is nie ... en dit bring weer die skuldgevoel en dan karring ons maar weer aan ... " (Alta).

Indien die persoon egter kan kom tot die ontdekking van 'n nuwe geloofswaarheid ten opsigte van sy konsep van God, kan hy sin ontdek in sy depressie. Deur geloofsinterpretasies op grond van die nuwe konsep van God, word die Goddelike moontlikheid as 'n realiteit beleef en word hoop gekonstitueer. 


\subsubsection{Depressie as sonde}

'n Verdere diskrepansie wat die persoon beleef, is dat hy nie is wat God van hom verwag om te wees nie en skuldgevoelens hieroor beleef. Teenoor die verwagting dat hy altyd blymoedig moet wees, is hy depressief. Hy beleef depressie dus as sonde of om in-die-skuld-te-wees by God. Deur dit wat medegelowiges sê, word hierdie belewenis van in-die-skuld-wees by God opnuut geaksentueer.

"Enne dit help nie om myself te verbeter as ek skuldgevoelens oor godsdiens en depressie en angs het nie. Skuldgevoelens ... hoe ek teenoor God voel ... en omdat ek nie die blydskap het wat die Bybel tog by 'n mens soek nie" (Alta)

Omdat geloof gesien word as voorwaarde vir 'n depressie-vrye lewe, is depressie by die gelowige ' $n$ anomalie. Die persoon beleef sy depressie as 'n gebrek aan geloofsvertroue. Hierdie gebrek aan geloof word selfs gesien as die oorsaak van die depressie. Op grond hiervan beleef die persoon geloofstwyfel en bevraagteken hy sy eie geloof. Die persoon twyfel of hy werklik gered is. Hy kan selfs so ver gaan om die gevolgtrekking te maak dat hy nie 'n gelowige is nie, en selfs sy geloof repudieer.

"Ek, ek beleef my depressie met ander woorde eintlik as sonde, nie ... nie as 'n, dis nie God wat faal nie, dis ek ... faal deur nie een honderd persent op Hom staat te maak vir my heil nie ... ja ... ja ... as ek eerlik moet wees ... ek erken dit nie graag, ek het dit nog nooit teenoor iemand erken nie ... ek erken dit nie eers graag teenoor myself nie ... maar $j a$ dit is so ' $n$ mens twyfel" (Clara).

\subsubsection{Depressie en die beoefening van religie}

Die persoon beleef dat sy religieuse praktyke tuis en gemeentelik, in kontras met die verlede, met inspanning gepaard gaan. Omdat die persoon lus is vir niks en opsien teen enige inspanning, lei dit daartoe dat hy homself onttrek en sy gemeentlike meelewing drasties ingekort word.

"My kerkbywoning het geweldig agteruitgegaan ... ek het die meeste van die tyd twee keer op 'n Sondag kerk toe gegaan ... ek kan nie eers onthou wanneer laas ek in die kerk was nie ... en dit het twee redes ... enersyds kom ek nie uit die bed uit nie ... dit is selfs moeilik om werk toe te gaan" (Clara).

Hy beleef die paradoks dat dit moeilik is om sy religieuse praktyke te beoefen ten spyte van 'n belewenis van geloofsverdieping. 
"Ek spooh nog verskriklik baie om genoeg aandag aan my Bybelstudie en persoonlike gebed (te gee), maar ek dink my geloof het 'n geweldige verdieping ondergaan die afgelope jaar" (Ben)

\subsubsection{Depressie en medegelowiges}

Die persoon beleef ' $n$ groot behoefte aan die bystand en ondersteuning van medegelowiges. In die lig van hierdie behoefte beleef die persoon egter grootliks 'n gebrek aan ondersteunig en begrip van medegelowiges.

"'n Mens (kry) nie in jou gemeente die die steun wat jy nodig het as jy dit nodig het nie" (Ben).

"Wat die gemeente betref, kry ek nie eintlik ondersteuning die ... ek dink nie hulle verstaan mooi wat ... wat depressie beteken nie" (Clara)

Die ondersteuning deur veral predikante word besonder hoog geag en die afwesigheid daarvan word as ' $n$ intense gemis beleef.

"Wel, daar is van die predikante wat weet dat ek depressief is, maar hulle het vir my een keer in Vista kom kuier ... maar sederdien het hulle nog nie weer naby my gekom nie ... en ... enne ek ervaar dit eintlik 'n bietjie ... moeiliker as wat ek graag wil toegee ... omdat ek regtig voel ... dit sou een steunpunt kon gewees het" (Clara)

Die opmerkings en raad van medegelowiges, wat berus op onkunde of onbegrip van die depressie, dra dikwels by tot die belewenis van depressie as 'n geloofstryd van diskrepansies en anomalieë. Hierteenoor beleef die depressiewe persoon waardevolle ondersteuning van medegelowiges wat uit eie ervaring begrip het vir depressie

\subsection{Die belewenis van depressie}

\subsubsection{Depressie as 'n onverwagse gebeurtenis}

Depressie word deur die gelowige as 'n totale, onverwagse skok beleef. Buiten dat die begrip depressiewe gelowige beskou word as 'n contradictio in terminis, is dit 'n skokervaring vir die gelowige om depressief te raak terwyl lly kerklik meelewend is en naby aan God leef.

"Ek was baie aktief in gemeentewerk in ons gemeente en ... hierdie ding (depressie) het my plat op die grond gedruk ek kon nie glo dat dit met my gebeur het nie ... en ontsettend baie laat twyfel aan my geloof en my geloofsekerheid" (Ben) 


\subsubsection{Depressie as 'n paradoksale verandering}

Die persoon beleef veranderinge wat hy nie kan versoen met sy premorbiede self nie. In kontras met die verlede beleef die persoon ' $n$ gevoel van verlaagde eiewaarde, ' $n$ totale lusteloosheid en verlaagde vitaliteit, 'n verlies aan sowel lewensvreugde as die vermoë om die lewe gelate te aanvaar, self-isolasie, ' $n$ veranderde belewenis van tyd soos verlede en toekoms, dag en nag, 'n belemmering van vermoëns en vaardighede, 'n pessimistiese lewensingesteldheid.

"Ek was altyd 'n vrolike mens ... op die oomblik is ek baie stil ... 'n afwesige mens ... wat vir my ontstellend is ... dit is vir my totaal abnormaal ... maar dit is hoe ek voel ... ek wil net in die kamer lê ... ek wil niks doen nie ... ek wil nie met mense kommunikeer nie" (Clara).

\subsubsection{Depressie as 'n sirkel-spiraal-belewenis}

Dié ervaring van depressie is een waarin die persoon 'n sirkulêre opwaartse en afwaartse beweging (verbeter en versleg) in 'n spiraal beleef. Die persoon beleef dat die een aspek van depressie aanleiding gee tot ' $n$ volgende en uiteindelik volg die bose kringloop van die depressie-spiraal.

"Wat wel gebeur as ek so voel, is dat ek onttrek ... gaan nie kerk toe nie ... en dan is ek nog kwaad vir die liewe Heer ook ... ek is kwaad omdat ek ongelukkig voel ... verskriklik kwaad ... en dan kry ek weer die skuldgevoel daaroor en dan werk dit in 'n bose kringloop" (Alta).

Die sirkelbeweging in die spiraal dui op die geloofs- en depressieparadokse waarvoor die persoon geen oplossing het nie. Die bose sirkel van die depressieparadoks is 'n kwadratuur van die sirkel. Kwadratuur van die sirkel verwys letterlik na die onmoontlikheid om met ' $n$ passer en ' $n$ liniaal ' $n$ vierkant te konstueer met dieselfde oppervlak as 'n gegewe sirkel óf figuurlik, na iets wat onuitvoerbaar, onmoontlik is (Odendaal et al,, 1979). Die depressieparadoks as ' $n$ kwadratuur van die sirkel dui dan op die onvermoë van die persoon om 'n oplossing vir die paradoks te kan bied. In terme van die geloofsparadoks, beteken dit dat die persoon vasgevang bly in die bose kringloop van die depressie, solank as wat hy ' $n$ oplossing probeer kry met behulp van sy bestaande apparatuur van 'n passer en 'n liniaal (of anders gestel, sy bestaande konsep van God as fides' quae). Die oplossing in terme van die sin en betekenis in die belewenis van depressie kan verkry word deur die bestaande apparatuur of eerder, sy konsep van God, aan te pas deur ' $n$ nuut ontdekte konsep van God. 'n Oplossing van die paradoks dui op die opwaartse beweging in die spiraal en 'n onvermoë om 'n antwoord te kry, gee aanleiding tot ' $n$ afwaartse beweging. Die sirkel-spiraal kan visueel soos in figuur 1 voorgestel word. 
Figuur 1: Depressie: 'n sirkel-spiraal-belewenis

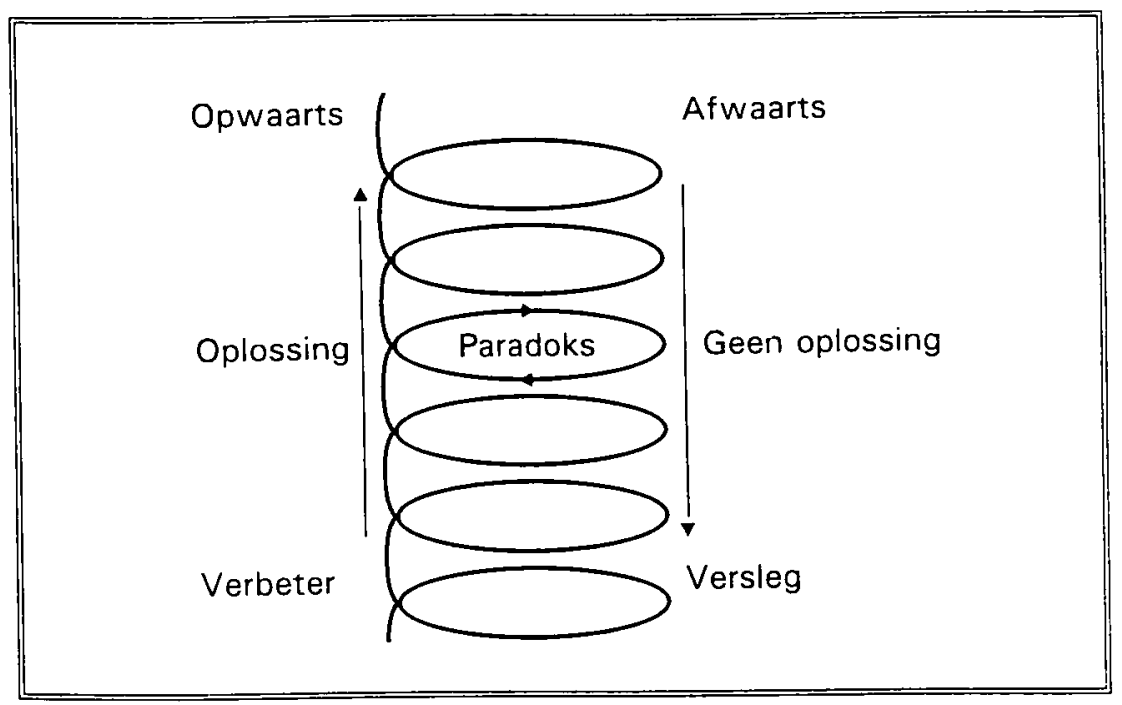

In figuur 1 dui die depressie-spiraal verder op die dinamiese interaktiewe, sirkulêre op- en afbeweeg in die spiraal waar verskeie faktore op 'n komplekse wyse met mekaar verband hou. Dit is dus nie moontlik om een aspek van die depressie uit te lig ten koste van ' $n$ ander nie.

\section{Bespreking}

Alhoewel hierdie ondersoek nie primêr gerig was op die patogenese van depressie nie, het die ondersoek tog ' $n$ belangrike bydrae in hierdie verband te lewer. Die resultate het eerstens gewys op die twee kemelemente, naamlik 'n verandering van die status quo en die oorskryding van die persoon se elastisiteitsperk vanweë veranderde eise - aspekte wat hy as oorweldigend beleef. Hierdie kernelement sluit nou aan by Tellenbach (1980) se onskrywing van 'n spesifieke situasie en spesifieke persoonlikheidstruktuur. Tellenbach (1980) beskryf die tipus melancholikus se essensiële kenmerk as die fiksasie op orde. Hierdie ondersoek sluit hierby aan deur te suggereer dat daar by die persoon aanduidings is van 'n ego-swakleid wat manifesteer in 'n rigiede ego. Hierdie persoon toon dan 'n verminderde buigsaamheid sodat hy geneig is om onder spanning te knak. Hierdie fiksasie op orde kan dui op ' $n$ verdedigingsmeganisme van ' $n$ reeds bedreigde ego. 
Tweedens verwys Tellenbach (1980) na die brugfase tussen die pre-melancholiese fase en die aanvang van die melancholiese episode as Verzweiflung. In wese is vertwyfeling die belewenis van ' $n$ paradoks wat die persoon nie in staat is om op te los nie. In hierdie ondersoek is dié aspek beskryf as ' $n$ belewenis van die sirkulêre paradoks en die sirkulêre opwaartse en afwaartse beweging in die depressie-spiraal. Hierdie beskrywing bevestig die belewenis van vertwyfeling, maar suggereer ' $n$ aanpassing en uitbreiding van Verzweiflung as brugfase. Vanweë die deurlopende temas van paradokse en diskrepansies waarbinne die depressiewe persoon vasgevang is en self nie ' $n$ oplossing kan vind nie, blyk dit dat Verzweiflung nie net beperk is tot die inisiële brugfase nie. Die belewenis van die paradoks is ' $n$ belangrike skakel in die bose kringloop of spiraal van depressie. Uit die vertellings het dit duidelik na vore gekom dat die paradoks lei tot die belewenis van die kenmerkende emosies van depressie soos ontsteltenis, skuldgevoelens, bekommernis, angs, ongelukkigheid en wanhoop. Hierdie belewenisse word gevolg deur ' $n$ intensifisering van die depressie. Dit is duidelik dat die belewenis van paradokse ' $n$ belangrike rol speel in sowel die patogenese as die instandhouding van depressie (vgl. Botha, 1991b).

By die religieuse persoon is die geloofsworstelstryd juis ' $n$ poging om ' $n$ antwoord te vind vir die paradoks van geloof. Die bronne van religieuse depressie volgens Cumbee (1980) wat in hierdie ondersoek bevestig is, is valse of neurotiese skuldgevoelens, wanhoop, Wurmteologie (onvermoë en magteloosheid), Uria-sindroom (om alleen gelaat te wees) en volgens Keady (1980), die konsep van God. Die rol wat predikante, medegelowiges en die kerklike dogma en praktyk in hierdie verband speel, is alreeds uitgewys en kan moeilik te veel beklemtoon word. Juis vanweë die depressiewe persoon se geneigdheid om te onttrek van interpersoonlike kontak en 'n verskeidenheid ander faktore soos onkunde aan die kant van medegelowiges, lei dit dikwels daartoe dat die depressiewe persoon beleef dat hy alleen gelaat word. Aan die ander kant is die interpersoonlike kontak en belangstelling deur medegelowiges van kardinale belang en behoort dit tot die essensie van die pastorale versorging van die depressiewe persoon. Omdat die depressiewe persoon worstel met geloofsparadokse is hy besonder ontvanklik vir geloofsuitsprake wat amptelik of informeel aan hom gekommunikeer word. Hierdie geloofsuitsprake kan dan of bydra tot die oplossing van sodanige paradoks of help om dit in stand te hou. Hierdie bronne kan almal saam gegroepeer word onder die tema van die paradoks wat manifesteer in belewenisse van diskrepansies en kontradiksies. In die lig van die bespreking hierbo is dit duidelik dat hierdie bronne of geloofsparadokse 'n belangrike rol speel in sowel die patogenese as die instandhouding van depressie. Dit is dus die onsuksesvolle oplossing van die geloofsparadokse wat dui op die patogenetiese rol van religie. Die suksesvolle oplossing van hierdie paradokse en in besonder die nuwe sin en betekenis wat ontdek word, dui op die remediërende rol van religie en geloof. Religie voorsien dus aan die gelowige ' $n$ kosmiese betekenissisteem waardeur sin 
en betekenis in die depressie ontdek kan word. Indien dit dan waar is van die depressiewe persoon, is dit ook waar van die gewone lidmaat wat deur religie betekenis ontdek en sy lewe verryk. So 'n persoon is minder kwesbaar en meer opgewasse teen die aanslae van die lewe. Die predikant kan in sy pastorale sorg erns maak met 'n religie wat die realiteite van die lewe in die oë kyk en so 'n bydrae lewer ten opsigte van die algemene geestesgesondheid van die gemeente.

Vanweë die depressiewe persoon se gefikseerdheid op die status quo, hou hy vas aan sy bestaande konsep van God. Indien hy poog om oplossings te kry op dieselfde wyses as wat hy vorige probleme opgelos het, bly hy vasgevang in die onmoontlikheid van die paradoksale situasie. Eers wanneer hy 'n antwoord soek in die buitengewone van 'n dikwels unieke en outentieke oplossing, kan hy ' $n$ oplossing vind vir die paradoks. Indien die persoon kan kom tot 'n outentieke Godskonsep (fides quae), kan hy kom tot 'n outentieke geloof (fides qua) waarin hy die moed het om te wees. Die essensiële vraag is dus: 'Bied die bestaande of die nuut ontdekte konsep van God vir die depressiewe persoon 'n antwoord op sy paradoksale belewenis van depressie?' Indien sy konsep van God nie 'n oplossing bied vir die paradoks nie, word die persoon oorval met wanhoop en bly hy vasgevang in die bose spiraal-kringloop van depressie. Indien sy konsep van God wel 'n oplossing bied, word sin en betekenis ontdek in die lyding en word hoop gekonstitueer. In hierdie verband blyk dit dat die konsep van God van kardinale belang is in sowel die opwaartse as die afwaartse beweging in die depressiespiraal. Dit is dus verder moontlik dat die konsep van God alreeds in die predepressiewe fase ' $n$ beslissende rol kon speel. In hierdie pre-depressiewe fase kan die konsep dus sowel 'n patogenetiese as 'n remediërende rol speel. Die vraag kan gevra word of die depressiewe persoon nie van die begin af ' $n$ 'foutiewe' konsep van God gehad het nie. Uit die bespreking sover is dit duidelik dat religie wel 'n patogenetiese en remediërende rol kan speel by die gelowige ten opsigte van depressie. Hierdie toedrag van sake hou belangrike pastoraal-gemeentelike asook terapeutiese en psigoterapeutiese implikasies in.

\subsection{Pastoraal-gemeentelike implikasies}

Werkswinkels behoort vir predikante gereël te word met die oog op die prediking en pastorale versorging van religieus depressiewe persone. Enkele aspekte wat aandag behoort te geniet sluit onder andere die volgende in:

* Die ontwikkeling van ' $n$ groter begrip vir depressie in die algemeen en in besonder by die gelowige as 'n geloofsworsteling met die gepaardgaande belewenis van geloofsparadokse.

* Die belang van pastorale versorging en die empatiese verstaan van depressiewe persone. Die volgehoue besoeke en ondersteuning van die ampsdraers en veral predikante is van uiterste belang. 
* Riglyne oor amptelike en pastorale Woordbediening behoort besondere klem te kry vanweë byvoorbeeld depressiewe persone se belewenis van ' $n$ oorsensitiewe gewete, in-die-skuld-wees en skuldgevoelens, die konsep van God en kerklike dogma (fides quae), kwelvrae soos selfmoord, opstand teen God en geloofsparadokse soos die diskrepansie tussen fides quae en fides $q u a$, tussen geloof (fides qaue en qua) en persoonlike ervaring.

* Oor die algemeen is dit van belang om te beklemtoon dat religie en geloof die potensiaal het om sowel 'n remediërende as 'n patogenetiese rol te kan vervul. Dit is belangrik om 'n openheid daar te stel vir die depressiewe persoon sodat hy aangemoedig word om in die fides quae te delf, dit te ondersoek en te bevraagteken. Op hierdie wyse kan hy nuwe dimensies en nuwe perspektiewe verkry waardeur nuwe en outentieke antwoorde moontlik is op die belewenis van paradokse

Hierdie ondersoek bevestig net weer die belang van psigo-pastorale opleiding tydens die studiejare van die predikant se opleiding.

Medegelowiges wat betrokke wil raak, kan geskool word en betrek word in kleingroepe en ondersteuningsgroepe vir die depressiewe persone. Die skoling van gemeentelede in die algemeen is van die uiterste belang omdat hulle die mense is met wie depressiewe persone dikwels kontak het.

\subsection{Psigoterapeutiese implikasies}

Indien 'n persoon na 'n psigiater verwys word, behoort die verwysing eers met die persoon deurgewerk te word om enige negatiewe belewenis in dié verband te ondervang. 'n Ego-ondersteunende benadering blyk aangedui te wees.

Vanweë die parataktiese distorsies in die metaforiese verhoudingsbeeld van God behoort dié aspek aandag te kry. Afhangende van die terapeut se benadering sou hierna verwys kon word as die deurwerk van oordrag (psigodinamies) of kognitiewe herstrukturering (kognitiewe benadering).

\section{Literatuurlys}

ARNDT, W.F. \& GINGRICH, F.W. 1979. A Greek-English Lexicon of the New Testament and Other Early Christian Literature. Chicago: The University of Chicago Press.

BECK A.T. 1976. Cognitive Therapy and the Emotional Disorders. New York: International Universities Press.

BENJAMIN, V.N. 1972. A Comparative Psychological Study of Religious Jews in Israel. Pretoria : Unisa. (M.A. Thesis.)

BLANKENBURG, W 1989. Wahnhafte und Nichtwahnhafte Depression. Daseinsanalyse, 6:40-56 
BOTHA, P.A. 1981. 'n Kritiese beskouing van H.M. Kuitert se boek. "Wat Heet Geloven? Struktuur en herkomst van de Christlijke geloofsuitpraken". Pretoria : Universiteit van Pretoria. (B.D.-skripsie.)

BOTHA P.A. 1991a. Melancholie en religie: 'n Fenomenologies-sielkundige ondersoek. Pretoria : Universiteit van Pretoria. (M.A.-verhandeling.)

BOTHA P.A. 1991b. Die rol wat die belewenis van paradokse speel in die patogenese en instandhouding van depressie. Referaat gelewer tydens die 10de Nasionale Kongres van die Sielkunde Vereniging van Suid-Afrika, 7-10 Oktober 1991

BOTHA P.A. 1992. Die rol wat die belewenis van paradokse speel in die patogenese en instandhouding van depressie. Propersona, 3(1):15-20.

CAMERON, M., \& RYCHLAK, J.F. 1985. Personality Development and Psychopathology A Dynamic Approach. Boston: Houghton Mifflin Company.

CUMBEE, D. W. 1980. Depression as an Ecclesiogenic Neuroses. The Journal of Pastoral Care, 34(4):254-267.

DU TOIT, G.F. 1984. Pastorale sorg aan die endogeen depressiewe persoon. Pretoria : Universiteit van Pretoria. (B.D.-skripsie.)

ELLISON, C.W., \& SMITH, J. 1991. Toward an Integrative Measure of Health and Wellbeing. Journal of Psychology and Theology, 19(1):35-48.

FLANNERY, R.B., \& BOWEN, M.J. 1984. Religious Values as a Moderator Variable of Life Stress. Journal of Pastoral Coumseling, 19:68-74

FREUD, S. 1971a. An Outline of Psycho-Analysis. (In Strachey, J. (Ed. and Trans.). The standard edition of the complete psychological works of Sigmund Freud (Vol. 19). London: Hogarth Press. (Original work published 1938.)

FREUD, S. 1971b. The Dynamics of Transference. (In Strachey, J. (Ed. and Trans.). The standard edition of the complete psychological works of Sigmund Freud (Vol. 12). London : Hogarth Press. (Original work published 1912.)

FREUD, S. 1971c. Mourning and Melancholia. (In Strachey, J. (Ed. and Trans.). The standard edition of the complete psychological works of Sigmund Freud (Vol. 14). London : Hogarth Press. (Original work published 1915.)

GARTNER, J., LARSON, D.B. \& ALLEN, G.D. 1991. Religious Commitment and Mental Health: A Review of the Empirical Literature. Journal of Psychology and Theology, 19:6-25.

GIORGI, A. (Ed). 1985. Phenomenology and Psychological Research. Pittsburgh : Duquesne University Press.

GRUBER, M.I. 1978. The Tragedy of Cain and Abel: A Case of Depression. The Jewish Quarterly Review, 69:89-97.

HARK, H. 1984. Religiöse Neurosen: Ursache und Heilung. Stuttgart : Kreuz Verlag.

HEINRICHS, D.J. 1982. Our Father Which Art in Heaven: Parataxic Distortions in the Image of God Journal of Psychology and Theology, 10(2):120-129.

JAMES, W. 1902. The Varieties of Religious Experience: A Study in Human Nature. New York : Longmans, Green \& Co.

JORDAAN, W.J. \& JORDAAN J.J. 1989. Mens in konteks. (2de uitgawe). Johannesburg : McGraw-Hill.

JORDAN, M.R. 1986. Taking on the Gods: The Task of the Pastoral Counselor. Nashville : Abingdon Press

JUNG, C.G. 1965. Answer to Job. (R.F.C. Hull, Trans.). London : Hodder and Stougton

KEADY, R.E. 1980. Depression, Psychology and the Concepts of God. Encoumer, 41:263277.

KRAUS, VON A. 1979. Sozialverhalten und Psychosenauslösung bei Manisch-Depressiven. Zeitschrift fiur Klimische Psychologie und Psychotherapie, 26:149-151. 
Depressie en religie

KRUGER, D. 1988. An Introduction to Phenomenological Psychology. Cape Town : Juta \& Co.

KVALE, S. 1983. The Qualitative Research Interview: A Phenomenological and Hermeneutical Mode of Understanding. Journal of Phenomenological Psychology, 14(2):171-196.

ODENDAAL, F.F., SCHOONEES, P.C., DU TOIT, S.J. \& BOOYSEN, C.M. 1979. Verklarende Handwoordeboek van die Afrikaanse Taal. Doornfontein : Perskor

MAY, R. 1939. The Art of Counselling. New York: Random House.

NUWE AFRIKAANSE BYBEL. 1983. Bybelgenootskap van Suid-Afrika Kaapstad : Nasionale Boekdrukkery.

POLKINGHORNE, D.E. 1989. Phenomenological Research Methods. (In Valle, R.S. \& Halling, S., Existential-Phenomenological Perspectives in Psychology: Exploring the Breadth of Human Experience. New York : Plenum Press. p. 41-60.)

POLOMA, M.M. \& PENDLETON, B.F. 1991. The Effects of Prayer and Prayer Experiences on Measures of Well-being. Journal of Psychology and Theology, 19(1):71-83.

POSTMA, F. 1982. Beknopte woordeboek: Latyns-Afrikaans (4de uitgawe). Kaapstad HAUM.

SULLIVAN, H. S. 1953. The Interpersonal Theory of Psychiatry. New York: W.W. Norton

SYKES, J.B. 1984. The Concise Oxford Dictionary. London : Oxford University Press

TELLENBACH, H. 1978. Das "Zwischen" und die Rolle: Zur Konditionsanalyse Endogener Psychosen. Zeitschrift fiur Klinische Psychologie und Psychotherapie, 26: 142-148.

TELLENBACH, H. 1980. Melancholy: History of the Problem, Endogeneity, Typology, Pathogenesis, Clinical Considerations. Pittsburgh : Duquesne University Press.

TELLENBACH, H. 1983. Phänomenologie der Schwermut. Zeitschrift für Klinische Psychologie, Psychopathologie und Psychotherapie, 31(2):100-113.

TILLICH, P. 1952. The Courage To Be. Fontana : Collins.

VAN DEN BERG, J.H. 1958. Psychologie en geloof. Nijkerk : G.F. Callenbach

VAN DEN BERG, J.H. 1974. Metabletica: Leer der veranderingen. Nijkerk : G.F. Callenbach.

VOSLOO, W. \& BISSCHOFF, J.H. 1989. Belewenisse en behoeftes van predikante: 'n Steekproef vir verdere ondersoeke. Ned Geref Teologiese Tydskrif, 30(4):563-573

WILSON, W.P. 1984. The Grace to Grow. Texas : Word Books.

WERTZ, F.J. 1983. From Everyday to Psychological Description: Analyzing the Moments of a Qualitative Data Analysis. Journal of Phenomenological Psychology, 14(2):197-141.

YALOM, I.D. 1980. Existential Psychotherapy. New York : Basic Books. 